\title{
Industry 4.0 and Smart Data as Enablers of the Circular Economy in Manufacturing: Product Re-Engineering with Circular Eco-Design
}

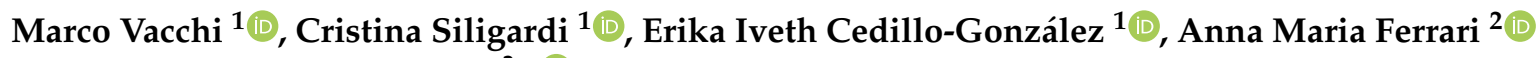 \\ and Davide Settembre-Blundo ${ }^{3, *}$ (D) \\ 1 Department of Engineering “Enzo Ferrari”, University of Modena and Reggio Emilia, 41125 Modena, Italy; \\ marco.vacchi@unimore.it (M.V.); cristina.siligardi@unimore.it (C.S.); ecedillo@unimore.it (E.I.C.-G.) \\ 2 Department of of Sciences and Methods for Engineering, University of Modena and Reggio Emilia, \\ 42122 Reggio Emilia, Italy; annamaria.ferrari@unimore.it \\ 3 Gruppo Ceramiche Gresmalt, Via Mosca 4, 41049 Sassuolo, Italy \\ * Correspondence: davide.settembre@gresmalt.it
}

Citation: Vacchi, M.; Siligardi, C.; Cedillo-González, E.I.; Ferrari, A.M.; Settembre-Blundo, D. Industry 4.0 and Smart Data as Enablers of the Circular Economy in Manufacturing: Product Re-Engineering with Circular Eco-Design. Sustainability 2021, 13, 10366. https://doi.org/10.3390/ su131810366

Academic Editors:

Gianmarco Bressanelli,

Federico Adrodegari, Daniela

Cristina Antelmi Pigosso and

Vinit Prida

Received: 15 August 2021

Accepted: 14 September 2021

Published: 16 September 2021

Publisher's Note: MDPI stays neutral with regard to jurisdictional claims in published maps and institutional affiliations.

Copyright: (c) 2021 by the authors. Licensee MDPI, Basel, Switzerland. This article is an open access article distributed under the terms and conditions of the Creative Commons Attribution (CC BY) license (https:/ / creativecommons.org/licenses/by/ $4.0 /)$.

\begin{abstract}
The digital transformation of manufacturing firms, in addition to making operations more efficient, offers important opportunities both to promote the transition to a circular economy and to experiment with new techniques for designing smarter and greener products. This study integrates Industry 4.0 technologies, smart data, Life Cycle Assessment methodology, and material microstructural analysis techniques to develop and apply a circular eco-design model that has been implemented in the Italian ceramic tile manufacturing industry. The model has been initially adopted in a simulation environment to define five different scenarios of raw material supply, alternative to the current production one. The scenarios were then validated operationally at laboratory scale and in a pilot environment, demonstrating that a proper selection of raw material transport systems significantly improves the environmental performance of the ceramic product. Both the results of the laboratory tests and of the pre-industrial experiments have demonstrated the technological feasibility of the solutions identified with circular eco-design, enabling the re-engineering of the ceramic product as the fifth of the 6 Rs of the circular economy.
\end{abstract}

Keywords: Industry 4.0; circular eco-design; re-engineering; sustainable manufacturing; smart data; raw material; ceramic tiles

\section{Introduction}

The manufacturing world has now taken up the challenge of the fourth industrial revolution, or Industry 4.0 [1], which is based on two foundations: automation [2] and data [3]. The new manufacturing paradigm of smart factories [4] is able to create environments that can adapt processes in real time to current needs through the elaboration of information based on the digital technologies of the Internet of Things [5]. Industry 4.0 pushes manufacturing industries to make their processes minimize waste: this transition to efficiency links Industry 4.0 with the goals of the circular economy [6]. This relationship becomes increasingly evident as companies define new strategies to achieve more ambitious environmental sustainability goals [7]. In fact, Industry 4.0 has a high potential to promote environmental sustainability because, unlike previous industrial revolutions, it is not accompanied by increased emissions or waste generation [8], but rather by increased operational efficiency [9] and organizational resilience [10]. To ensure successful optimization of manufacturing operations and improve production efficiency, an integrated MES (Manufacturing Execution System), ERP (Enterprise Resource Planning), and PLC (programmable logic controller) system was implemented. Thanks to these digital systems, it is possible to manage, monitor, and coordinate the execution of real-time physical processes 
providing feedback on process performance. In addition, to follow the environmental aspects into product and process development, the insertion of intelligent and interconnected sensors and PLCs in the production lines enables automated data collection for dynamic life cycle assessment (LCA) analysis [11]. The integration of simulation modelling with LCA increases predictive capacity in terms of environmental sustainability and circular eco-design, drastically reducing the reaction time of the company and its operational efficiency. Environmental impact assessment can also be combined with economic [12], social [13], or technological [14] impact assessment for a more complete view of the degree of sustainability. Alternatively, LCA, LCC, and S-LCA can be integrated with each other in a holistic methodological approach called Life Cycle Sustainability Assessment (LCSA) [15]

This efficiency can not only be determined in real time, but thanks to simulation environments where the physical and virtual worlds come together, it is possible to predict the behavior of production systems by anticipating errors and improving decision-making processes [16]. Thus, the simulation environment can improve efficiency in the exploitation of natural resources, energy, and other inputs, as well as in the development of closed-loop processes within the supply chain [17]. From an organizational point of view, Industry 4.0 leads to the transformation of the traditional factory into an effective smart factory [18] that, due to its intrinsic characteristics, is more efficient and therefore potentially more sustainable and able to implement the characteristic aspects of the circular economy [19], i.e., the so-called 6Rs: reduce, reuse, recycle, recover, redesign, and remanufacture [20]. To implement this change in corporate culture, however, it is necessary to innovate not only technologies, but also organizational paradigms and, therefore, business models [21]. Among these, circular business models [22] involve the development of products as service models [23], for which servitization becomes the way to extend their life cycle [24]. Extending the life cycle of products means keeping their value, and the resources used to manufacture them as long as possible within the economic loop [25]. Therefore, the impact level on the environment, economy, and society will be lower.

In a technologically advanced production framework, as smart factories are [26], the efficient use of production factors is already a given. Implementing at least four of the six $\mathrm{R}$ actions (reduce, reuse, recycle, recover) that characterize the circular economy is, therefore, easier. The real challenge for manufacturing companies is instead the redesign of products [27] and, therefore, of the entire value chain [28]. Eco-design [29], a methodology for product design in which sustainability issues (environmental, but also socio-economic) are considered during the product development process as an additional factor to those traditionally used for decision-making, can help manufacturing companies [30]. Eco-design simultaneously considers all the fundamental elements that make a product marketable, from its aesthetic characteristics to its functional performance, also evaluating all the phases of its production and distribution chain, in addition to the socio-economic and commercial factors [31,32]. In this life cycle approach (understood as the set of stages in the useful life of a product up to the final management of its waste), the product is not the final destination but a temporary state of matter and energy that can provide the consumer with a use and service benefit [33]. Therefore, from a circular economy perspective, eco-design is one of the main ways to re-engineer products so that they are high quality as well as ecological and socially responsible.

As previously pointed out, the literature evidences the benefits that manufacturing firms can reap from the synergistic relationship between digital technologies and the reengineering of products [34], processes [35], and entire supply chains [36] in a circular economy perspective [37]. However, having the right technologies is not always a sufficient and necessary condition to change the operational paradigm. In this regard, Zheng et al. [38] point out that there is still a lack of comprehensive research on the applications of Industry 4.0 enabling technologies in manufacturing life cycle processes. The digital transformation of industrial sectors also leads companies to address a new reality in which physical and virtual resources are integrated into a single production system. Among virtual resources, data are an important raw material able to produce organizational knowl- 
edge if manufacturing firms can turn Big Data (collected in an Industry 4.0 environment) into Smart Data (able to generate value). Lacam and Salvetat [39] argue that Smart Data cannot replace Big Data, but both domains work in a synergistic relationship through a virtuous cycle of data exploitation. These authors also emphasize that it is not necessary to mine a large amount of data to extract value from it. Even how to capture and exploit a smaller volume of useful data for a specific purpose has not yet been adequately explored in the literature. The latest literature explores the barriers to the circular economy and sustainability implementation in an Industry 4.0 environment [40]. However, empirical studies with quantitative approaches are lacking, and most studies are conceptual or qualitative [41].

This paper, therefore, aims to fill the literature gap regarding the role played by smart manufacturing techniques in the adoption of circular economy practices [42], and how to transform part of Big Data into Smart Data [39], focusing on the re-engineering of the product and input sourcing system in an operational environment with a quantitative approach [41]. To achieve this goal, the study analyzes the manufacturing process of ceramic tiles for construction in Italy, a resource-intensive industry [43] with a complex input sourcing system [44], a high level of adoption of Industry 4.0 digital technologies [45,46], and characterized by the implementation of internationally recognized environmental best practices [11]. From the environmental point of view, the Italian ceramic industry, thanks to continuous investments, can count on more sustainable technologies with pollution levels well below the legal limits and on the Best Available Techniques (BATs) [47].

Based on what is stressed above, we can formulate the following Research Question:

- RQ: Is it possible to validate through a feasibility study the hypothesis that Industry 4.0 digital technologies can work as an enabling operating environment for the Circular Economy?

The article is structured as follows. Section 2 outlines the research methodology with a statement of the techniques applied. In Section 3, the experimental part is explained, namely the circular eco-design in a simulation environment, the tests at laboratory scale, and finally, the experimentation in the industrial environment. In addition, the potential of the obtained results is also discussed. Finally, conclusions are drawn in Section 4.

\section{Materials and Methods}

\subsection{Industrial Background and Methodological Design}

The ceramic tile manufacturing industry is a sector that requires significant amounts of natural resources (raw materials) and energy (methane gas and electricity) [11]. Italian companies use, on average, about $20 \mathrm{~kg}$ of a mix of raw materials called ceramic body to manufacture 1 square meter of tiles [48]. In 2020, the Italian ceramic industry produced 344.3 million square meters of tiles [49], so the natural raw material requirement was:

$$
344.3 \text { million } \mathrm{m}^{2} \times 20 \mathrm{~kg} / \mathrm{m}^{2}=6.886 \text { million tons }
$$

The main material supply sources of the Italian ceramic industry are located in Turkey (sodium feldspar), Ukraine (ball clays), Germany (ball clays), and, to a lesser extent, in Italy (potassium feldspar, kaolinitic volcanic clays, and sands) [44]. Recent studies carried out in the same industry have shown that the environmental impact of the finished product is attributable not only to the production process in the strict sense but also to the raw material sourcing system. Thus, sourcing logistics offers significant opportunities for improving environmental criticality [11].

This research was conducted with the methodological approach of the single in-depth case study [50] considered appropriate to draw inductive inferences to gain a better understanding of the re-engineering potential phenomenon [51]. Moreover, this methodological approach is the one most widely employed in the literature in studies related to the operating environment of Industry 4.0 [52-57]. As a case study, a company was selected among the TOP 10 Italian producers of ceramics and among the TOP 5 for economic perfor- 
mance, which produces the tile type of porcelain stoneware [58]. The same company has already been successfully engaged as a case study in research in the field of sustainability management $[46,59,60]$.

In this study, the raw material sourcing system is optimized by re-engineering processes and materials supported by eco-design to achieve circular economy goals and improve the environmental performance of the ceramic product. In particular, the activity is directed to reduce the distances between the factory and mines and consider more ecological transport systems. The aim is to minimize the environmental impact while respecting the constraint of technological feasibility through the reformulation of the compositions of ceramic bodies by maximizing the amount of local or European raw materials to the detriment of non-EU ones. The digital technologies of Industry 4.0 enable this development. Thanks to the process data collected in real-time in the factories, it is possible to build a predictive model of alternative scenarios' environmental and technological performance.

\subsection{Environmental Assessment and Eco-Design}

According to Directive 2009/125/EC [61], eco-design integrates environmental aspects into product design to improve the product's environmental performance during its life cycle. The key methodology of eco-design is the Life Cycle Assessment [62], a tool that investigates and evaluates the environmental impacts of a product or service during all phases of its existence: extraction, production, distribution, use, and end of life. The framework documents for conducting a Life Cycle Assessment are the international standards ISO 14040 (principles and framework for LCA) and ISO 14044 (requirements and guidelines for LCA) [63]. In this study, eco-design, based on LCA, consists of performing consecutive studies on the current composition of ceramic body by making variations in resource inputs and estimating the different environmental impacts until the formula with the most negligible impact is identified. However, unlike the traditional LCA approach that is based on the analysis of historical data-for example, considering the previous year than the time when the study is conducted-in this research, we will exploit the potential of Industry 4.0 for the collection of process data in real time. This means that a dynamic, and not static, eco-design will be conducted, based on information about consumption and emissions collected at the very moment they are realized thanks to digital technologies. In this way, it is possible to give the modeling carried out with eco-design an even more prospective vision from the present to the future, which overturns the traditional approach of eco-design that is based instead on the scheme from the past to the present.

\subsection{Sample Preparation}

Table 1 shows the six different ceramic body compositions, where $\mathrm{C} 1$ was used as starting composition.

Table 1. Raw materials $[64,65]$ (wt.\%) composition of the ceramic body mixtures.

\begin{tabular}{ccccccc}
\hline Raw Materials (wt. $\%)$ & C1 & C2 & C3 & C4 & C5 & C6 \\
\hline Ukraine Clay & 30 & 25 & 20 & 15 & 10 & $/$ \\
German Clay & 15 & 20 & 20 & 25 & 25 & 30 \\
Turkish Na-Feldspar & 37 & 35 & 30 & 25 & 20 & 20 \\
Italian Clay & $/$ & $/$ & 10 & 15 & 20 & 30 \\
Italian K-Feldspar & 10 & 10 & 10 & 10 & 15 & 15 \\
Italian Feldspar Sand & $/$ & $/$ & 10 & 10 & 10 & 5 \\
Italian Quartz Sand & 8 & 10 & $/$ & $/$ & $/$ & $/$ \\
Extra-EU raw materials (wt. $\%)$ & $\mathbf{6 7}$ & $\mathbf{6 0}$ & $\mathbf{5 0}$ & $\mathbf{4 0}$ & $\mathbf{3 0}$ & $\mathbf{2 0}$ \\
\hline
\end{tabular}

The sample preparation route for laboratory samples can be summarized as follows: dry raw materials, pre-grinded by a dry route to a particle size $<100 \mu \mathrm{m}$, were carefully weighted (Bel Engineering M120A Model Analytical balance, $\pm 0.0001 \mathrm{~g}$ ) and wet-milled in a porcelain jar (500 $\mathrm{g}$ of dry powder mixture and $270 \mathrm{~g}$ of deionized water) using alumina 
balls (500 g, mixture of sizes with diameters in the range 9-18 $\mathrm{mm}$ ) as grinding media. Tripolyphosphate ( $0.75 \mathrm{~g}$ in $500 \mathrm{~g}$ of dry powder mixture) was added as a deflocculant. Following milling, the slip was dried at $110^{\circ} \mathrm{C}$, and the resulting powder cake was disaggregated and moisturized (6 wt.\%). Disc-shaped ceramic bodies with a diameter of ca. $50 \mathrm{~mm}$ were obtained by dry-pressing of the moist powder $(40 \mathrm{MPa})$. The samples of ceramic bodies prepared in this way were dried at $110{ }^{\circ} \mathrm{C}$ and then fired in a roller kiln at a maximum temperature of $1220^{\circ} \mathrm{C}$ with a 40 min cycle.

\subsection{Sample Characterization}

Chemical analyses of the mixtures of the raw materials were performed by X-ray Fluorescence Spectroscopy (XRF) on fused glass discs using a ARL 9400 XP instrument. Before sample fusion, the Loss on Ignition (LOI) was determined gravimetrically following roasting at $1050^{\circ} \mathrm{C}$ for $2 \mathrm{~h}$.

Quantitative phase analyses of raw materials mixtures and fired ceramic bodies were performed using X-ray powder diffraction (XRPD) data. Data were collected using a $\theta / \theta$ diffractometer (PANalytical, $\mathrm{CuK} \alpha$ radiation) equipped with a fast real-time multiple strip detector (step scan of $0.0167^{\circ} 2 \theta$ ). Divergence and anti-scattering slits of $0.5^{\circ}$ were included in the incident beam optics with 0.04 rad soller slits and a beam mask of $15 \mathrm{~mm}$. The diffracted beam passed through an anti-scatter blade, a 0.04 rad soller slit and a Ni-filter. The wet-grinded and moisturized powder mixtures used to prepare ceramic bodies were analyzed following equilibrating with ambient conditions. Instead, fired bodies were first ball-milled in an agate jar for $20 \mathrm{~min}$ followed by drying $\left(110^{\circ} \mathrm{C},>2 \mathrm{~h}\right)$. The dry powder was subsequently mixed with a standard (10 wt.\% NIST 676a) before data collection. The addition of an internal standard allowed us to perform a full quantitative phase analysis, including the amorphous fraction, using the Rietveld method and rescaling following a previously described procedure [66]. The refinements were accomplished with the GSASEXPGUI package $[67,68]$. The use of an internal standard with certified unit cell also abled the determination of absolute unit cell parameters of the phases.

Particle sizing of the mixtures of the raw materials was performed by laser diffraction using a Mastersizer 2000 (Malvern Instruments) equipped with a system for measuring in a liquid (Hydro 2000S). Water was used as a carrier fluid for these analyses. Sintering of the ceramic bodies was followed in situ using Optical dilatometry (Misura ODHT-HSM instrument, model 1600-80, Expert System Solutions) in the temperature range $25-1400{ }^{\circ} \mathrm{C}$ using a heating rate of $10^{\circ} / \mathrm{min}$. The measurement output was the dimensional variation of a parallelepiped $\left(15 \times 5 \times 5 \mathrm{~mm}^{3}\right)$, carved from the disc-shaped dry ceramic body, as a function of temperature.

Thermogravimetry in conjunction with Differential Scanning Calorimetry (TG/DSC) was performed using a Netzsch STA 429 instrument. Data were recorded in an air atmosphere in the temperature range $25-1400{ }^{\circ} \mathrm{C}$ using a heating rate of $10^{\circ} / \mathrm{min}$.

\section{Results and Discussion}

\subsection{Circular Eco-Design}

Within the $6 \mathrm{R}$ methodology, the ceramic industry is characterized by very efficient production processes despite the need to use significant amounts of raw materials and energy resources. The result obtained by these industries is already oriented to rationalizing production resources, completely reusing both processing waste and industrial water. With this starting base, already performing well from the environmental point of view, as also highlighted in the literature [11,47], as an area of improvement and in a circular economy perspective, this research focused on the $\mathrm{R}$ of the redesign of the ceramic product to make it even more environmentally performing. In this case, the redesign has been executed as re-engineering, i.e., applying the digital technologies of the smart factory to make the ceramic product even more sustainable.

A ceramic porcelain stoneware body is mainly made up of three main categories of raw materials that give the product different technological properties: clays (plasticity 
during pressing) [65], feldspars (glass formation and fusibility during firing) [69], and sands and feldspathic sands (formation of crystalline structure during firing) [70]. The eco-design phase began with the production composition labeled C1 in Table 1 to formulate replacement compositions. The eco-design in the simulation environment foresaw a progressive decrease in Ukrainian clay and Turkish sodium feldspar, to the advantage of German clay and other domestic raw materials that are closer at the production plant. In fact, the transportation system is different depending on the origin of raw materials:

- Ukrainian clay: train + ship + truck;

- Turkish feldspar: truck + ship + truck;

- German clay: truck + train + truck;

- Domestic raw materials: truck only.

From an environmental point of view, German clay has an advantage because its transportation is mostly by train that is a lower impact transport system than truck [71], and the distance covered is shorter than the Ukrainian clay, while domestic raw materials benefit from the shorter distance between mine and factory.

In order to confirm these hypotheses, the Dynamic Life Cycle Assessment system already developed by Ferrari et al. [72] and based on the real-time collection of process data thanks to the IoT technologies of Industry 4.0 was used.

The ceramic tile manufacturing process consists of several steps that are illustrated in Figure 1a. Raw materials from the mines are stored in the warehouse waiting to be mixed according to the composition of the body. The mixture is introduced in a cylindrical mill containing silica pebbles as grinding bodies and water as grinding vehicle in a solid/liquid ratio of $66 \% / 33 \%$. The milled mixture, in the form of a solid/liquid suspension called slurry, is dried and converted into a granular powder through a vertical spray dryer. The powder is then pressed to form ceramic tiles which, after drying to remove residual moisture, are glazed and digitally decorated with special inks. The glazed and decorated products are then transferred to the roller kiln for firing, after which the products can be cutting and possibly lapped as a final finishing step. Finally, the tiles are selected on the basis of their geometric and aesthetic conformity and packaged to be sent to distributors. Each of the described phases has a system of sensors connected to each other through cabling and/or Wi-Fi network, which collect process data to send them to the factory Manufacturing Execution System (MES). The new circular eco-design model depicted in Figure $1 \mathrm{~b}$ leverages the vast amount of process-related data (Big Data) and collected through line sensors connected to the MES that links the factory with Enterprise Resource Planning (ERP). A Business Intelligence (BI) application selects only those data contained in the ERP that are critical (Smart Data) to carry out the real-time Life Cycle Inventory (BI-LCI). The LCI is the basis for performing environmental impact assessment with Dynamic Life Cycle Assessment (LCA).

The functioning of the dynamic environmental assessment system is shown in Figure 1. The different design scenarios, corresponding to the compositions from $\mathrm{C} 1$ to $\mathrm{C} 6$ shown in Table 1, were tested in a simulation environment using process data collected in real time at the factory. In other words, it was simulated to produce a batch of $100,000 \mathrm{~m}^{2}$ of tiles for each type of ceramic body, keeping the other process parameters fixed. Thanks to the Dynamic Life Cycle Assessment, the environmental impact was predicted for each composition. This phase of the study was enabled by the digital technologies of Industry 4.0 which allow us not only to collect processed data, but also to process it, in real time. Therefore, the manufacturing model of Industry 4.0 enables the smart exploitation of the large amount of production data to perform a dynamic inventory analysis and environmental assessment in the sourcing and manufacturing phases of the product life cycle. 


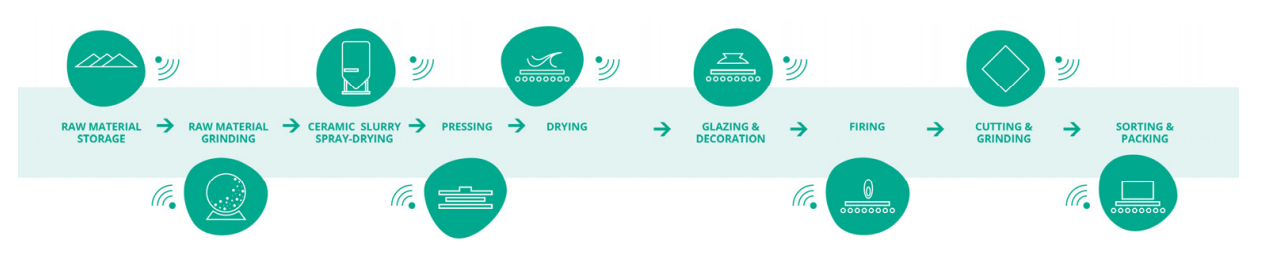

(a)

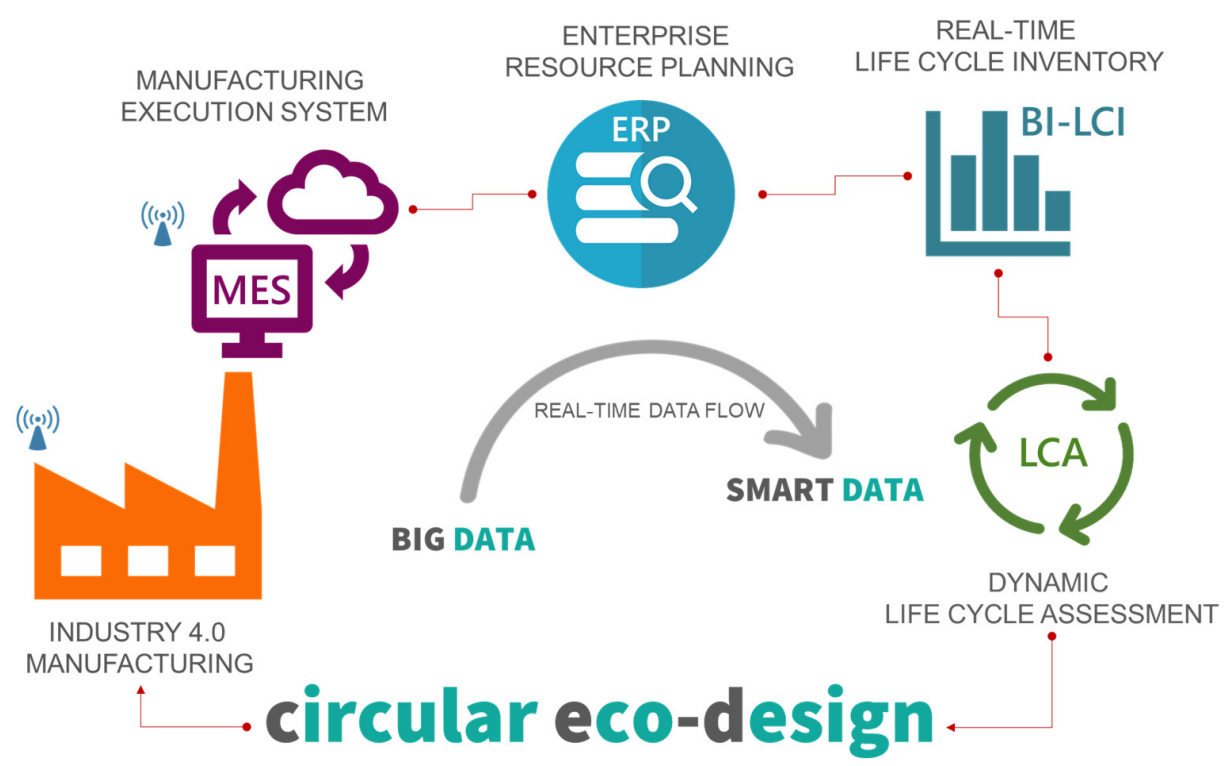

(b)

Figure 1. (a) Ceramic tile manufacturing process phases and (b) integration of Industry 4.0, Smart Data and Dynamic LCA in the new circular eco-design model (modified from the model proposed by [65]).

The results of the Dynamic Life Cycle Assessment are detailed in Table 2.

Table 2. Environmental impacts of $1 \mathrm{~m}^{2}$ of ceramic tiles $\left(19.9 \mathrm{Kg} / \mathrm{m}^{2}\right)$.

\begin{tabular}{|c|c|c|c|c|c|c|c|c|c|}
\hline $\begin{array}{l}\text { Product Life } \\
\text { Cycle Stages }\end{array}$ & Composition & GWP & ODP & AP & EP & РОCP & ADPE & ADPF & $\begin{array}{c}\text { TOTAL } \\
\text { DAMAGE }\end{array}$ \\
\hline & & $\begin{array}{c}\text { [kg CO} \mathrm{CO}_{2} \\
\text { eq.] }\end{array}$ & $\begin{array}{c}\text { [kg CFC-11 } \\
\text { eq] }\end{array}$ & {$\left[\mathrm{kg} \mathrm{SO} \mathrm{S}_{2}\right.$ eq. $]$} & $\begin{array}{c}{\left[\mathrm{kg}\left(\mathrm{PO}_{4}\right)^{3-}\right.} \\
\text { eq. }]\end{array}$ & $\begin{array}{c}{\left[\mathrm{kg} \mathrm{C} \mathrm{C}_{2} \mathrm{H}_{4}\right.} \\
\text { eq. }]\end{array}$ & [kg Sb eq.] & {$[\mathrm{MJ}]$} & {$[\mathrm{kPt}]$} \\
\hline \multirow{6}{*}{$\begin{array}{l}\text { Raw materials } \\
\text { and chemicals } \\
\text { sourcing } \\
\text { (Modules } \\
\text { A1-A2) }\end{array}$} & $\mathrm{C} 1$ & 3.49 & $1.91 \times 10^{15}$ & $1.95 \times 10^{-2}$ & $5.51 \times 10^{-3}$ & $6.23 \times 10^{-4}$ & $6.84 \times 10^{-5}$ & $4.49 \times 10^{1}$ & $1.50 \times 10^{-6}$ \\
\hline & $\mathrm{C} 2$ & 3.32 & $4.95 \times 10^{-7}$ & $1.85 \times 10^{-2}$ & $5.25 \times 10^{-3}$ & $6.09 \times 10^{-4}$ & $6.56 \times 10^{-5}$ & $4.26 \times 10^{1}$ & $1.43 \times 10^{-6}$ \\
\hline & $\mathrm{C} 3$ & 3.05 & $4.62 \times 10^{-7}$ & $1.65 \times 10^{-2}$ & $4.74 \times 10^{-3}$ & $5.63 \times 10^{-3}$ & $6.37 \times 10^{-5}$ & $3.95 \times 10^{1}$ & $1.32 \times 10^{-6}$ \\
\hline & C4 & 2.81 & $4.25 \times 10^{-7}$ & $1.50 \times 10^{-2}$ & $4.35 \times 10^{-3}$ & $5.39 \times 10^{-4}$ & $6.08 \times 10^{-5}$ & $3.64 \times 10^{1}$ & $1.22 \times 10^{-6}$ \\
\hline & C5 & 2.59 & $3.94 \times 10^{-7}$ & $1.33 \times 10^{-2}$ & $3.89 \times 10^{-3}$ & $5.09 \times 10^{-5}$ & $5.88 \times 10^{-5}$ & $3.38 \times 10^{1}$ & $1.12 \times 10^{-6}$ \\
\hline & $\mathrm{C} 6$ & 2.32 & $3.53 \times 10^{-7}$ & $1.15 \times 10^{-2}$ & $3.41 \times 10^{-3}$ & $4.80 \times 10^{-4}$ & $5.60 \times 10^{-5}$ & $3.05 \times 10^{1}$ & $1.01 \times 10^{-6}$ \\
\hline $\begin{array}{c}\text { Tiles } \\
\text { manufacturing } \\
\text { (Modules A3) }\end{array}$ & $\mathrm{C} 1-\mathrm{C} 6$ & 7.21 & $2.07 \times 10^{15}$ & $8.34 \times 10^{-3}$ & $1.71 \times 10^{-3}$ & $6.68 \times 10^{-4}$ & $1.03 \times 10^{-5}$ & $1.10 \times 10^{2}$ & $2.01 \times 10^{-6}$ \\
\hline $\begin{array}{l}\text { Tiles transport } \\
\text { and } \\
\text { installation } \\
\text { (Modules } \\
\text { A4-A5) }\end{array}$ & $\mathrm{C} 1-\mathrm{C} 6$ & 5.75 & $5.48 \times 10^{14}$ & $2.13 \times 10^{-2}$ & $4.91 \times 10^{-3}$ & $1.03 \times 10^{-3}$ & $7.79 \times 10^{-5}$ & $5.45 \times 10^{1}$ & $1.93 \times 10^{-6}$ \\
\hline $\begin{array}{c}\text { Tiles use } \\
\text { (Modules } \\
\text { B1-B7) }\end{array}$ & $\mathrm{C} 1-\mathrm{C} 6$ & 1.51 & $7.59 \times 10^{14}$ & $7.57 \times 10^{-3}$ & $5.81 \times 10^{-3}$ & $8.08 \times 10^{-4}$ & $4.47 \times 10^{-5}$ & $1.80 \times 10^{1}$ & $2.10 \times 10^{-6}$ \\
\hline $\begin{array}{c}\text { Tiles } \\
\text { end-of-life }\end{array}$ & $\mathrm{C} 1-\mathrm{C} 6$ & 0.04 & $1.39 \times 10^{13}$ & $4.44 \times 10^{-4}$ & $7.37 \times 10^{-5}$ & $1.53 \times 10^{-5}$ & $1.85 \times 10^{-6}$ & $9.25 \times 10^{-1}$ & $3.37 \times 10^{-8}$ \\
\hline
\end{tabular}

As shown in Figure 2, the environmental results of the different Product Life Cycle Stages are the same for the considered compositions except for raw materials and chemical sourcing because of the influence of the different scenarios of raw materials supply. 


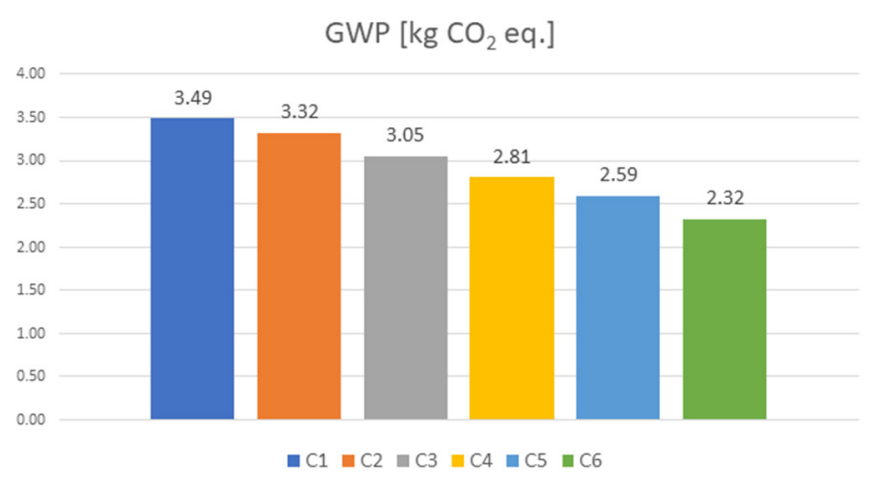

(a)

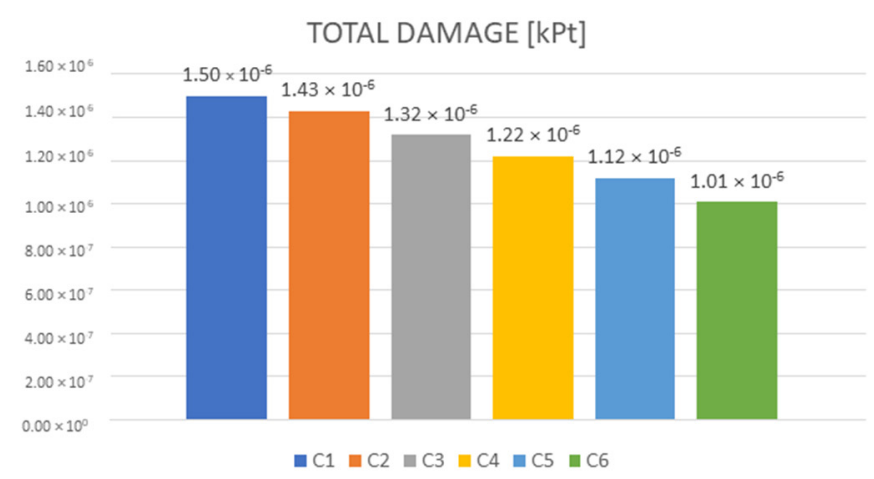

(b)

Figure 2. Variation of the indicators Global Warming Potential (a) and Total Damage (b) related to modules A1-A2 of different compositions of ceramic bodies.

The Dynamic Life Cycle Assessment is a model based on the Ecoinvent 3.6 database [73] within the Simapro 9.1.1 [74] calculation code, which integrates a detailed midpoint analysis with an aggregated endpoint analysis. The impacts assessment was conducted using the CML-IA baseline [75] method for midpoint indicators and the IMPACT 2002+ method [76], to evaluate the aggregate endpoint indicator "Total Damage". The midpoint analysis uses the following impact categories: Global Warming Potential (GWP), Ozone Depletion Potential (ODP), Acidification Potential (AP), Eutrophication Potential (EP), Photochemical Ozone Creation Potential (POCP), Abiotic Depletion Potential for Non-fossil Resources (ADPE), and Abiotic Depletion Potential for Fossil Resources (ADPF). The total damage indicator is calculated by normalizing and weighting the results obtained for each damage category (Human Health, Climate Change, Resources, and Ecosystem Quality), which allows us, through a single value expressed in environmental points ( $\mathrm{kPt}$ ), to compare the different scenarios.

In accordance with ISO 14040 and ISO 14044, $1 \mathrm{~m}^{2}$ of porcelain ceramic tiles was chosen as the functional unit to conduct the impact assessment. At the same time, the system boundaries were set from cradle-to-grave. The mass of the functional unit is $19.9 \mathrm{~kg} / \mathrm{m}^{2}$. Table 2 shows the results obtained for each ceramic body composition by stage of the life cycle. In detail, the phase of extraction of raw materials and production of chemical compounds and their transport to the ceramic tile factory is followed by the manufacturing phase (body grinding and spray-drying; pressing and drying; glaze grinding, glazing and decoration; firing; finishing; sorting and packaging) and then the transport to the building with installation, use, and end of life that closes the cycle.

Following the new standard EN 15804:2012+A2:2019 [77] that regulates the development of Environmental Product Declarations (EPDs) for the construction sector, the table shows the mandatory modules for each phase of the life cycle: the production processes of energy and natural resources (A1); the transport of resources to the factory (A2); the production process of the tiles (A3); the transport of the ceramic product from the production plant to the building site (A4); the installation phases of the tiles (A5); the period of use (B1), maintenance cleaning (B2); repair, replacement and refurbishment of the product (B3, B4, B5); finally, the use of energy (B6) and water (B7) for the operation of the building. Similarly to what occurs in EPD documents, in Table 2, the modules are aggregated to represent the main phases of the ceramic product life cycle.

The different scenarios considered in this study change how the raw materials that make up the ceramic body are sourced, so these changes' effect on environmental impact is only evident in modules A1-A2. Therefore, the other phases of the life cycle and the corresponding modules remain unchanged as basic assumptions for eco-design. Figure 2 presents the trends of the midpoint indicator GWP and the endpoint indicator Total Damage for the supply modules (A1-A2). 
GWP is a crucial indicator because it is closely related to the use of fossil fuels in transport systems, while Total Damage, as an endpoint indicator, provides a holistic estimate of environmental damage. The values assumed by all midpoint indicators in modules A1-A2 predict that the progressive change in the supply system towards the use of raw materials closer to the manufacturing unit or employing a more ecological transport system such as the train significantly reduces environmental impact. This is well evidenced by the endpoint indicator (Total Damage, Figure $2 b$ ), which decreases progressively from composition C1 to C6. In this forecast, the GWP drops by 33.6\% and the Total Damage by $32.4 \%$ when switching from the old production composition (C1) to the new (C6) with potentially eco-friendly raw materials. These predictive results provided by dynamic ecodesign, using production data collected in real time with Industry 4.0 technologies, show that a different way of selecting raw materials significantly improves the environmental performance of the ceramic product. The results obtained provide the environmental validation to carry out the re-engineering of the raw material sourcing system. However, to implement the real re-engineering of the process, empirical verification is needed to show how much the different compositional solutions are technologically feasible.

\subsection{Ceramic Bodies Testing}

Mixtures of the different green ceramic bodies corresponding to the compositions shown in Table 1 were screened for mineralogical and chemical characterization. Tables 3 and 4 show the mineralogical and chemical compositions of the raw materials and ceramic bodies, respectively.

Table 3. Mineralogical composition of the green ceramic bodies.

\begin{tabular}{ccccccc}
\hline \multirow{2}{*}{$\begin{array}{c}\text { Body } \\
\text { Composition }\end{array}$} & \multicolumn{5}{c}{ Main Mineralogical Phases (wt.\%) } \\
\cline { 2 - 7 } & Quartz & Kaolinite & Illite/Mica & Plagioclase & K-Feldspar & Calcite \\
\hline C1 & $27.4 \pm 0.2$ & $19.1 \pm 0.4$ & $11.0 \pm 0.5$ & $38.8 \pm 0.3$ & $3.2 \pm 0.4$ & $0.4 \pm 0.1$ \\
C2 & $30.9 \pm 0.2$ & $21.9 \pm 0.3$ & $7.1 \pm 0.3$ & $36.0 \pm 0.3$ & $3.7 \pm 0.7$ & $0.4 \pm 0.1$ \\
C3 & $36.7 \pm 0.2$ & $13.1 \pm 0.4$ & $10.3 \pm 0.3$ & $38.5 \pm 0.3$ & $1.4 \pm 0.2$ & - \\
C4 & $32.3 \pm 0.2$ & $13.1 \pm 0.5$ & $16.0 \pm 0.6$ & $30.8 \pm 0.3$ & $6.9 \pm 0.4$ & $0.8 \pm 0.1$ \\
C5 & $38.9 \pm 0.2$ & $13.1 \pm 0.4$ & $12.1 \pm 0.4$ & $26.1 \pm 0.3$ & $8.9 \pm 0.2$ & $0.9 \pm 0.1$ \\
C6 & $33.4 \pm 0.2$ & $12.8 \pm 0.3$ & $16.5 \pm 0.3$ & $28.4 \pm 0.2$ & $8.4 \pm 0.2$ & $0.5 \pm 0.1$ \\
\hline
\end{tabular}

Table 4. Chemical composition of the ceramic bodies.

\begin{tabular}{ccccccc}
\hline \multirow{2}{*}{$\begin{array}{c}\text { Oxide } \\
\text { (wt.\%) }\end{array}$} & $\mathbf{C}$ 1 & $\mathbf{C 2}$ & $\mathbf{C} 3$ & $\mathbf{C 4}$ & $\mathbf{C 5}$ & C6 \\
\cline { 2 - 7 } & 66.68 & 67.27 & 67.74 & 68.24 & 69.11 & 69.79 \\
$\mathrm{SiO}_{2}$ & 20.56 & 20.05 & 19.51 & 19.00 & 18.16 & 17.35 \\
$\mathrm{Al}_{2} \mathrm{O}_{3}$ & 0.83 & 0.86 & 0.90 & 0.98 & 1.02 & 1.09 \\
$\mathrm{Fe}_{2} \mathrm{O}_{3}$ & 0.76 & 0.69 & 0.68 & 0.61 & 0.56 \\
$\mathrm{TiO}_{2}$ & 0.77 & 0.76 & 0.44 & 0.43 & 0.41 & 0.38 \\
$\mathrm{MgO}$ & 0.46 & 0.45 & 0.62 & 0.58 & 0.62 & 0.61 \\
$\mathrm{CaO}$ & 0.90 & 0.94 & 3.49 & 3.05 & 2.60 & 2.60 \\
$\mathrm{Na} 2 \mathrm{O}$ & 4.00 & 3.81 & 2.58 & 2.75 & 3.14 & 3.22 \\
$\mathrm{~K}_{2} \mathrm{O}$ & 1.95 & 1.93 & 4.12 & 4.35 & 4.36 & 4.36 \\
$\mathrm{LOI}$ & 3.93 & 4.00 & & & &
\end{tabular}

The clay fraction is composed of kaolinite and illite, whereas the melt minerals are plagioclase with minor amounts of K-feldspars. Quartz is present in various amounts, ranging from ca. 27-39 wt.\%. The good thermal stability of quartz during the firing cycle, with only partial melting, renders this mineral suitable as a ceramic backbone [78]. The successive replacement of extra-EU raw materials with raw materials coming from within the European Union leads to an increased quartz content, a more illitic character of the clay fraction, and a decreased plagioclase/K-feldspar ratio (Table 3) [78]. 
These mineralogical variations are reflected in the chemical compositions (Table 4). The various amounts of K-bearing minerals, i.e., illite/mica and K-felspars, present in the bodies determine important variations mainly in the concentration of alkali metal oxides.

Compared to the production composition (C1), which presents a $\mathrm{Na}_{2} \mathrm{O} / \mathrm{K}_{2} \mathrm{O}$ ratio strongly unbalanced towards sodium $\left(\mathrm{Na}_{2} \mathrm{O} / \mathrm{K}_{2} \mathrm{O}=2.05\right)$, the alternative scenarios move towards a rebalancing of this ratio due to the reduction in imported sodium feldspar in the compositions $\left(\mathrm{Na}_{2} \mathrm{O} / \mathrm{K}_{2} \mathrm{O}\right.$ is $1.97,1.35,1.11,0.83$, and 0.81 for $\mathrm{C} 2, \mathrm{C} 3, \mathrm{C} 4, \mathrm{C} 5$, and $\mathrm{C} 6$ compositions, respectively). Technological tests will have to demonstrate the feasibility of this change in terms of sintering level, i.e., it will have to be verified that the porosity of the ceramic body complies with the requirements set by current standards. The $\mathrm{SiO}_{2} / \mathrm{Al}_{2} \mathrm{O}_{3}$ ratio $\left(\mathrm{SiO}_{2} / \mathrm{Al}_{2} \mathrm{O}_{3}=3.24\right.$ for $\left.\mathrm{C} 1\right)$ also increases progressively in $\mathrm{C} 2-\mathrm{C} 6$ compositions $\left(\mathrm{SiO}_{2} / \mathrm{Al}_{2} \mathrm{O}_{3}\right.$ is $3.36,3.47,3.59,3.81$, and 4.02 for $\mathrm{C} 2, \mathrm{C} 3, \mathrm{C} 4, \mathrm{C} 5$, and $\mathrm{C} 6$ compositions, respectively) and this could have repercussions on linear shrinkage during the firing phase of the tiles. Likewise in this case, the technological tests must ascertain the feasibility of these variations.

The six compositions (C1-C6) were then milled as described in Section 2.2, and particle size analyses were conducted on the powders obtained.

Figure 3 shows the grain size distributions of the ceramic body mixtures.

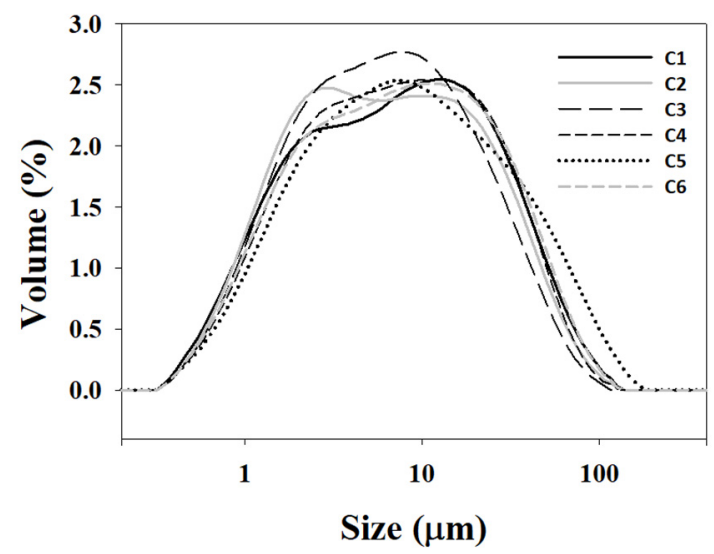

Figure 3. Grain size distributions of the ceramic body C1-C6 mixtures measured by laser diffraction.

The distributions are rather similar, indicating comparable grindabilities. The ranges are broad, going from the lower detection limit of the laser diffraction instrument $(0.01 \mu \mathrm{m})$ up to ca. $100 \mu \mathrm{m}$ with values of $\mathrm{D}(90), \mathrm{D}(50)$, and $\mathrm{D}(10)$ being in the ranges $1.3-1.5 \mu \mathrm{m}$, 6.4-8.2 $\mu \mathrm{m}$, and 29-47 $\mu \mathrm{m}$, respectively. These results are in line with those generally found for wet-grinded ceramic powders for the manufacturing of porcelain stoneware tiles [79].

\subsection{In Situ Thermal Analyses}

Thermal expansion tests were then performed on the same powders as the milled bodies. Figure 4 shows expansion (\%) as a function of temperature obtained by dilatometry experiment of the dry bodies.

For comparison, the first derivative curves are also depicted. Apart from the sudden expansion in the transition range of quartz $(\alpha \rightarrow \beta)$ around $573{ }^{\circ} \mathrm{C}$, a positive linear trend is observed up to about $950{ }^{\circ} \mathrm{C}$ followed by a first small contraction step (TS1 in Figure 4). The main contractions step (TS2) starts at ca. $1100{ }^{\circ} \mathrm{C}$ and is assigned mainly to viscous sintering triggered by the melting of the feldspars. The maximum sintering rate, indicated by the minimum point of the first derivative curve, is found at a temperature of ca. $1200{ }^{\circ} \mathrm{C}$. In order to shed light on these events, TG/DSC measurements were performed; for example, the results for composition $\mathrm{C} 4$ are shown in Figure 5. 

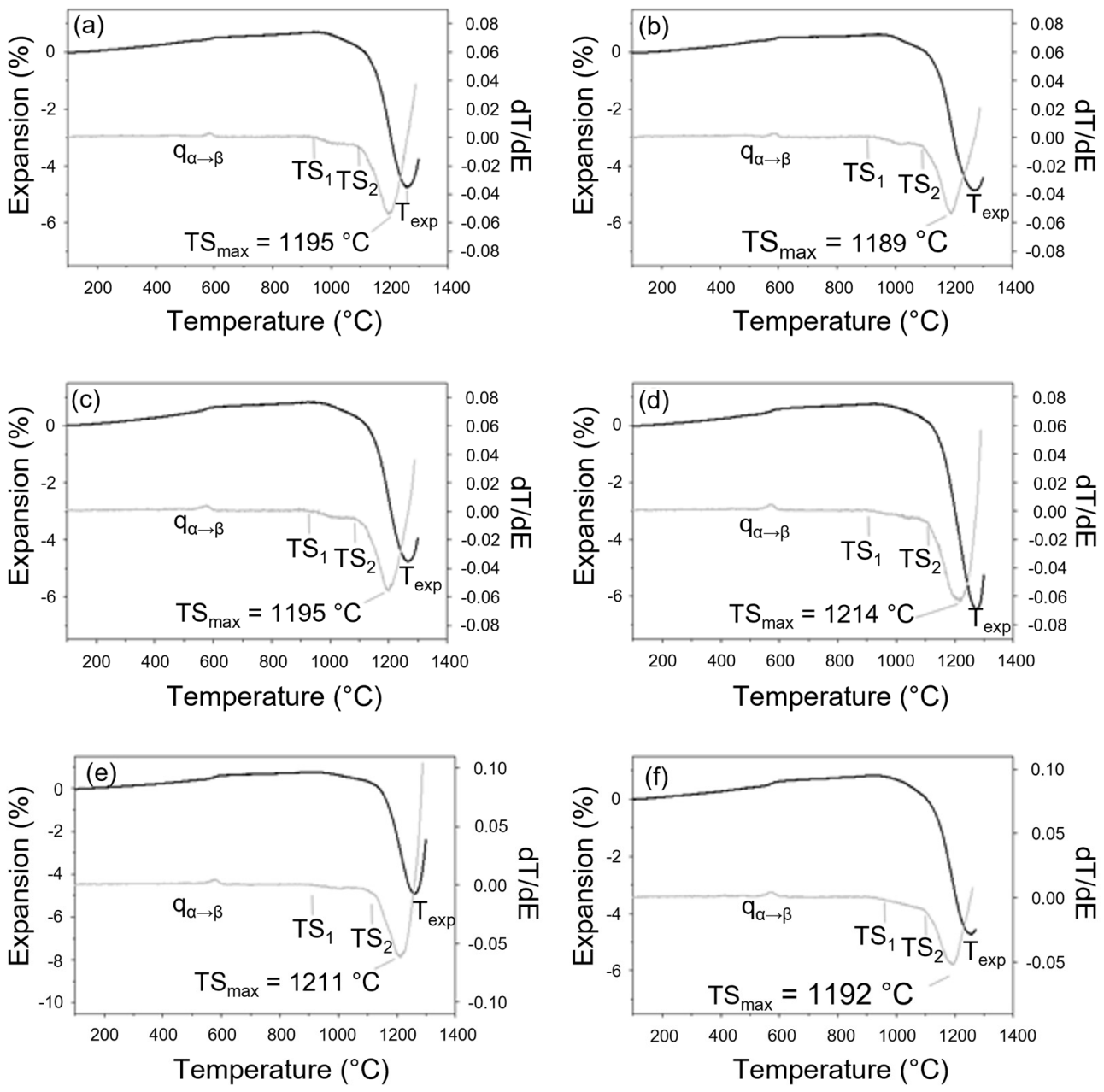

Figure 4. Expansion (\%) (black curves) and dT/dE (gray curves) as functions of temperature obtained by dilatometry experiment of the dry-pressed ceramic bodies. Curves (a-f) correspond to Expansion and $\mathrm{dT} / \mathrm{dE}$ curves of body compositions $\mathrm{C} 1-\mathrm{C} 6$, respectively.

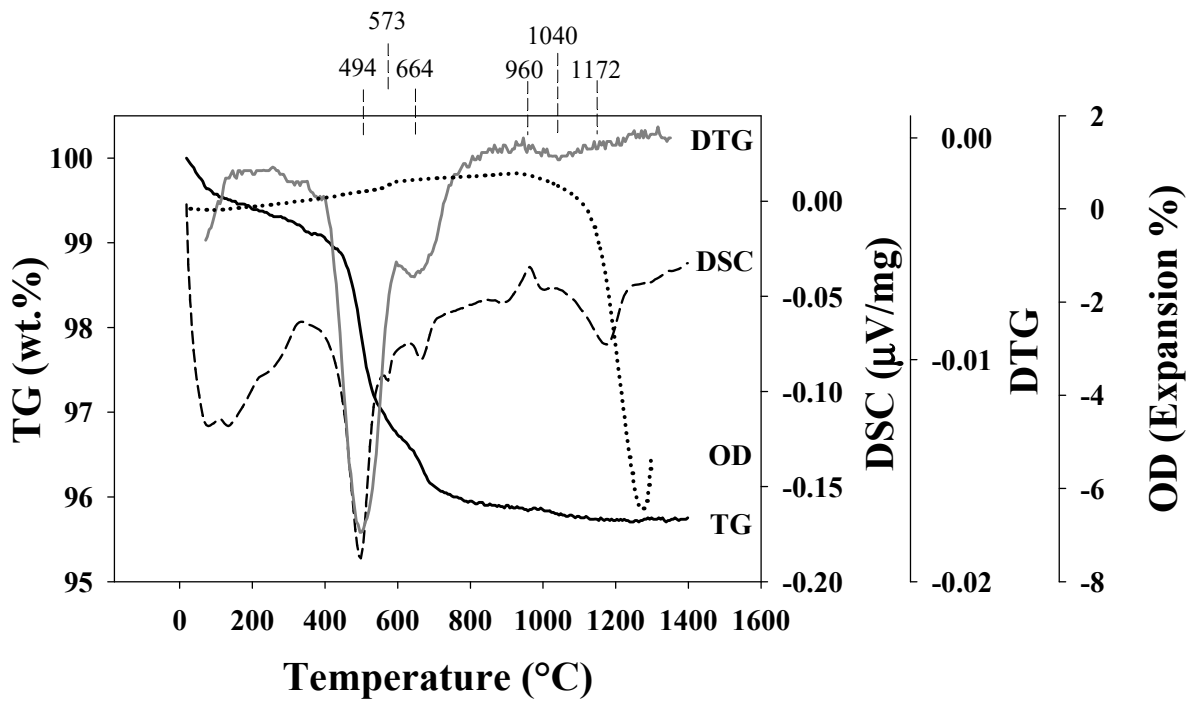

Figure 5. TG/DSC results for composition C4. For comparison, the expansion curve obtained from dilatometry measurements (also shown in Figure 4d) is also displayed.

For comparison, the expansion curve obtained from optical dilatometry is also displayed. The following dehydration and possibly also decomposition of organic matter 
naturally present in the raw materials and/or added to the slip as dispersant (endothermic band at $\mathrm{T}<\mathrm{ca} .340^{\circ} \mathrm{C}$ ), two important endothermic events are observed at $494{ }^{\circ} \mathrm{C}$ and $665^{\circ} \mathrm{C}$ which are assigned to dehydroxylation of kaolinite and illite, respectively [80]. The $\alpha \rightarrow \beta$ transition of quartz is also evident at $573{ }^{\circ} \mathrm{C}$. An exothermic peak is observed at $960^{\circ} \mathrm{C}$ and is assigned to the crystallization of primary mullite from the dehydroxylated clay minerals. The endothermic peak at $1176{ }^{\circ} \mathrm{C}$ is assigned to the melting of feldspars. The TG/DTA curves show a minor weight loss in the range $960-1170{ }^{\circ} \mathrm{C}$. A trace amount $(<1 \%)$ of calcite is present in the starting compositions (see Table 3 ) but is expected to decompose at a lower temperature $\left(<900^{\circ} \mathrm{C}\right)$. Instead, this event is assigned to dehydroxylation of mica, structurally similar to illite but known to display considerably higher dehydroxylation temperature. Rodriguez-Navarro et al. [81] studied the temperature-induced breakdown of muscovite and found that temperatures higher than $900{ }^{\circ} \mathrm{C}$ triggered dehydroxylation followed by partial melting and crystallization of mullite. The authors observed bubbles of trapped water molecules (TEM analyses) due to overlapping of dehydroxylation and melting, only developing under fast-firing conditions such ceramic firing. The phase transitions/transformations observed by TG/DTA are reflected in the dilatometry curve (see Figure 4). The volume expansion due to the phase transition of quartz is evident. The first contraction step (i.e., TS1 in Figure 4) is in concomitance with the crystallization of primary mullite and possibly also to the dehydroxylation of mica (see Figure 5). The endothermic peak assigned to feldspar melting perfectly matches the major contraction in the optical dilatometry curve due to viscous sintering. It is interesting to observe that the high-temperature weight loss assigned to dehydroxylation of mica overlaps with the formation of a viscous melt (Figure 5). This should further contribute to the formation of closed porosity triggered by water molecules entrapped in the viscous melt.

\subsection{Microstructural Properties of the Fired Ceramic Bodies}

The in situ sintered samples, after thermal analysis, were submitted to microstructural analysis to highlight the effect of thermic treatment on the ceramic bodies. Figure 6 shows the quantitative phase analyses (XRPD and Rietveld-RIR) of the fired ceramic bodies.

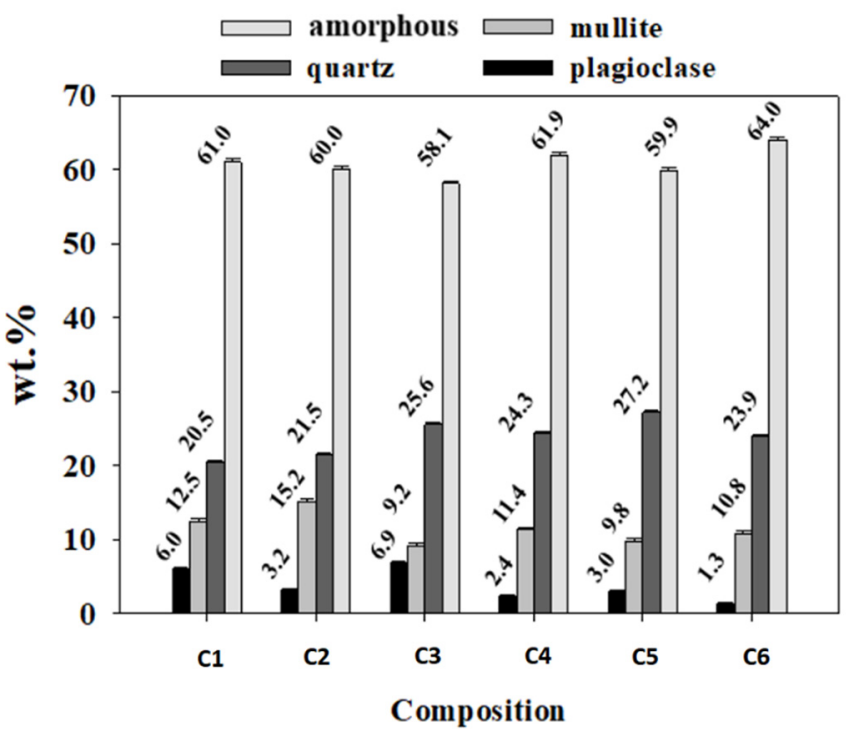

Figure 6. Results from full quantitative phase analyses (XRPD and Rietveld-RIR) of the fired ceramic bodies.

The Rietveld refinement output of the fired ceramic body obtained from composition C6 is shown in Figure 7 for demonstrative purpose. 


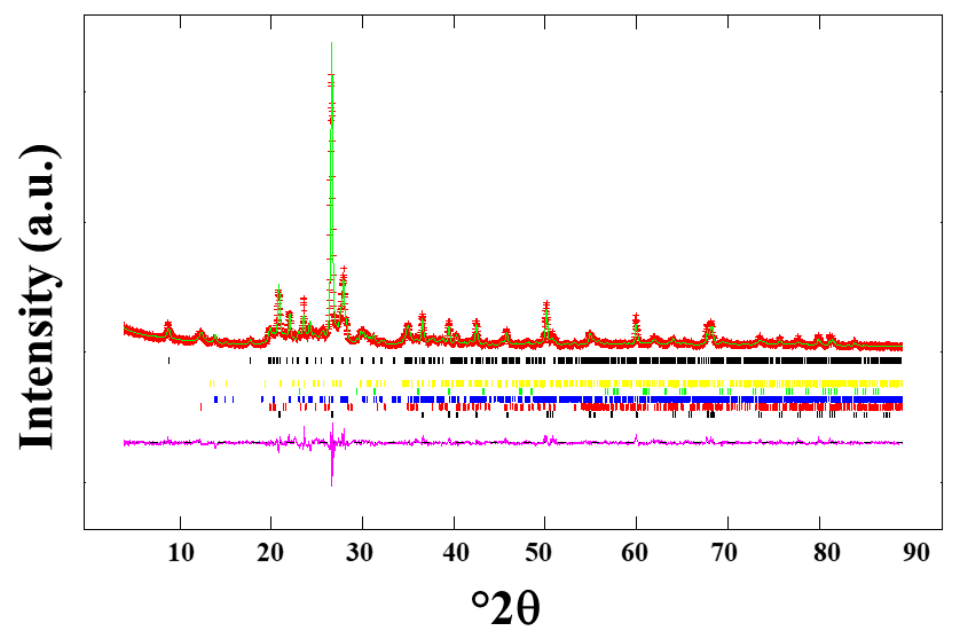

Figure 7. Rietveld refinement output for composition C6. The observed, calculated (red, above), and difference (pink, down) curves are depicted. Starting from the top, the following phases are indicated with tick marks: illite/mica; K-feldspar; calcite; plagioclase; kaolinite; quartz. "a.u" identifies the number of photons counted by the detector of the XRD, " $2 \theta^{\prime \prime}$ stands for the angle between the detector and the electron beam [82].

As shown in Figure 6, the vitreous phase is by far the most abundant phase ranging from $60-64 \mathrm{wt} . \%$. The amount of residual quartz (20-27 wt.\%) is linearly proportional with the quantity present in the starting mixtures, although about $30 \mathrm{wt} . \%$ lower due to partial melting during firing. The presence of mullite $(9-15 \mathrm{wt} . \%)$ is correlated to the amount of kaolinite and illite/mica in the starting compositions. Some residual feldspars (1-7 wt.\%) are also detected. Zanelli et al. [78] performed full quantitative phase analyses of 40 industrial tiles from various manufacturers in addition to 53 tailored compositions processed in a pilot plant. The authors found that the amorphous content lies in the range $40-75 \mathrm{wt} . \%$, whereas the contents of quartz, mullite, and feldspars are in the ranges $11-31 \mathrm{wt} . \%, 2-15 \mathrm{wt} . \%$, and $0-15 \mathrm{wt} . \%$, respectively. Taking these values as references, we can thus conclude that the phase compositions of the ceramic bodies investigated here are typical for porcelain stoneware.

The chemical composition and the phase composition of the fired ceramic bodies were used to determine the vitreous phase's chemical composition by subtracting the crystalline phases' contribution from the overall chemical composition. The results are shown in Table 5.

Table 5. Chemical composition amorphous fraction.

\begin{tabular}{ccccccc}
\hline $\begin{array}{c}\text { Oxide } \\
\text { (wt. \%) }\end{array}$ & $\mathbf{C 1}$ & $\mathbf{C 2}$ & $\mathbf{C 3}$ & $\mathbf{C 4}$ & $\mathbf{C 5}$ & C6 \\
\hline $\mathrm{SiO}_{2}$ & 70.8 & 71.7 & 70.0 & 70.1 & 70.1 & 71.2 \\
$\mathrm{Al}_{2} \mathrm{O}_{3}$ & 17.3 & 16.2 & 17.5 & 15.8 & 16.0 & 15.4 \\
$\mathrm{Fe}_{2} \mathrm{O}_{3}$ & 0.8 & 1.1 & 0.9 & 1.9 & 1.4 & 1.7 \\
$\mathrm{TiO}_{2}$ & 0.8 & 1.1 & 1.0 & 1.0 & 1.0 & 0.8 \\
$\mathrm{MgO}$ & 0.4 & 0.6 & 0.4 & 0.7 & 1.0 & 0.6 \\
$\mathrm{CaO}$ & 1.2 & 1.2 & 0.7 & 1.6 & 1.9 & 1.0 \\
$\mathrm{Na}_{2} \mathrm{O}$ & 5.8 & 5.7 & 6.5 & 4.0 & 3.9 & 3.8 \\
$\mathrm{~K}_{2} \mathrm{O}$ & 3.0 & 2.4 & 3.0 & 4.9 & 4.6 & 5.5 \\
\hline
\end{tabular}

For these calculations, the chemical compositions of residual feldspars were assumed to be that of pure Na-feldspar $\left(\mathrm{NaAlSi}_{3} \mathrm{O}_{8}\right)$ and $\mathrm{K}$-feldspar $\left(\mathrm{KAlSi}_{3} \mathrm{O}_{8}\right)$. Instead, the stoichiometry of mullite was determined to be $3 \mathrm{Al}_{2} \mathrm{O}_{3} \cdot 2 \mathrm{SiO}_{2}$ by using the refined a-axis length and its relation to the $\mathrm{mol} \% \mathrm{Al}_{2} \mathrm{O}_{3}$ [83]. The resulting chemical composition of the glassy phase was subsequently used to calculated the shear viscosity as a function of temperature 
using the model proposed by Giordano et al. [84]. The applicability of this model was recently verified by Conte et al. [85].

Figure 8 shows the resulting curves as well as the specific values at maximum firing temperature. The trends observed for the different compositions are similar, with values at maximum firing temperature ranging from 4.87-5.06 $\log 10$ Pas. Conte et al. [85] reported that viscous sintering in porcelain stoneware tiles is accomplished with a glassy phase with a viscosity of about 4.5-5.4 $\log 10$ Pas, which is perfectly in line with our observations. The trend of melt viscosity as a function of temperature was obtained by applying the model described by Giordano et al. [84]. The calculated viscosity at the maximum firing temperature is inserted for comparison. Although these are complex mixtures of oxides, it is possible to provide a qualitative explanation for the viscosity values obtained by correlating them with the composition of the six formulations. $\mathrm{C} 2$ and $\mathrm{C} 6$, which have the highest viscosity values, contain a greater amount of silicon, behaving as a glass former. The higher amount of sodium present in C3, on the other hand, returns a more open and weak structure, thus behaving as a glass modifier and lowering the viscosity of the system.

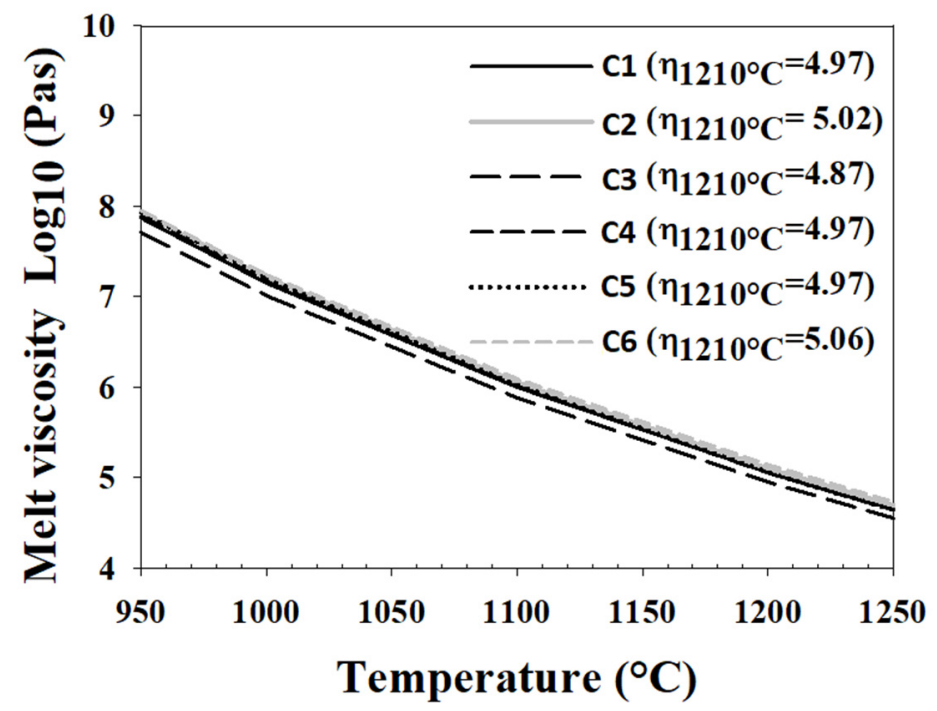

Figure 8. Melt viscosity of the ceramic bodies.

\subsection{Technological Properties of Fired Ceramic Bodies}

In order to test the technological feasibility of the studied compositions of mixture, prototypes of tiles have been realized in a pilot environment. For this reason, the six body compositions were milled in an industrial mill. The slips obtained were spray-dried to obtain powders pressed with a pilot hydraulic press at a pressure of $40 \mathrm{MPa}$, thus repeating the same operating conditions of the laboratory tests. The $646 \times 646 \mathrm{~mm}$ tiles were then dried to remove residual humidity and fired in an industrial roller kiln at a maximum temperature of $220^{\circ} \mathrm{C}$ with a 40 min cycle.

Technological performance indicators are shown in Table 6, namely, dimensional conformity, which is measured by comparing the effective length with the nominal length (ISO 10545-2) (the measurements were performed with CNE100 $1000 \mathrm{~mm}$ fiftiethsimal caliper, \pm 0.02$)$; water absorption conformity which is measured under vacuum according to ISO 10545-3 [86] (the measurements were performed with Bel Engineering M6202Di Model Precision balance, $\pm 0.01 \mathrm{~g}$ ); and flexural strength according to ISO 10545-4 [87] (the measurements were performed with Gabbrielli Technology Flexi 1000 LX-650, $\pm 100 \mathrm{~g}$ ). Linear shrinkage of fired tiles was determined as the difference between the length of unfired and fired samples [88]. Finally, the table also shows the content of extra-European raw materials to show the evolution of the body compositions concerning the sourcing alternatives. 
Table 6. Technological performance of the ceramic bodies.

\begin{tabular}{ccccccc}
\hline Technological Properties & \multicolumn{5}{c}{ Composition of Ceramic Bodies } \\
\cline { 2 - 6 } & C1 & C2 & C3 & C4 & C5 & C6 \\
\hline Extra-EU raw materials (wt.\%) & 63 & 57 & 52 & 42 & 26 & 20 \\
Length (nominal N = 604 mm) & $603.7 \pm 0.1$ & $601.3 \pm 0.1$ & $604.6 \pm 0.1$ & $608.1 \pm 0.1$ & $605.1 \pm 0.1$ & $603.2 \pm 0.1$ \\
Linear shrinkage (\%) & $6.55 \pm 0.02$ & $6.92 \pm 0.02$ & $6.41 \pm 0.02$ & $5.87 \pm 0.02$ & $6.33 \pm 0.02$ & $6.63 \pm 0.02$ \\
Dimensional conformity (ISO 10545-2) & $\mathrm{N} \pm 2.0 \mathrm{~mm}$ & $\mathrm{~N} \pm 2.0 \mathrm{~mm}$ & $\mathrm{~N} \pm 2.0 \mathrm{~mm}$ & $\mathrm{~N} \pm 2.0 \mathrm{~mm}$ & $\mathrm{~N} \pm 2.0 \mathrm{~mm}$ & $\mathrm{~N} \pm 2.0 \mathrm{~mm}$ \\
Water absorption (\%) & $0.39 \pm 0.01$ & $0.18 \pm 0.01$ & $0.49 \pm 0.01$ & $0.61 \pm 0.01$ & $0.52 \pm 0.01$ & $0.27 \pm 0.01$ \\
Water absorption conformity & $\leq 0.5 \%$ & $\leq 0.5 \%$ & $\leq 0.5 \%$ & $\leq 0.5 \%$ & $\leq 0.5 \%$ & $\leq 0.5 \%$ \\
$\quad$ (ISO 10545-3) & $1749 \pm 1$ & $1592 \pm 1$ & $1482 \pm 1$ & $1420 \pm 1$ & $1510 \pm 1$ & $1767 \pm 1$ \\
Bending strength (N) & $\geq 1300 \mathrm{~N}$ & $\geq 1300 \mathrm{~N}$ & $\geq 1300 \mathrm{~N}$ & $\geq 1300 \mathrm{~N}$ & $\geq 1300 \mathrm{~N}$ & $\geq 1300 \mathrm{~N}$ \\
Bending strength conformity & & & & & &
\end{tabular}

All compositions are compliant with respect to flexural strength. However, compositions $\mathrm{C} 2$ and $\mathrm{C} 4$ are out of standard, although for different reasons. C2 is too sintered, and this is evidenced by the very low water absorption $(0.18 \%)$ and small size $(601.3 \mathrm{~mm})$ due to the high shrinkage (6.92\%). On the contrary, C4 is a very refractory composition. The high absorption $(0.61 \%)$ determines the high dimensions $(608.1 \mathrm{~mm})$ due to the low shrinkage (5.87\%). Compositions C 3 and C5 are at the limit of acceptability thresholds for high absorption, $0.49 \%$ and $0.52 \%$, respectively. Finally, compositions $\mathrm{C} 1$ and $\mathrm{C} 6$ are similar in terms of technological compliance despite having very different compositions in terms of raw materials: $63 \%$ of extra-EU resources against $20 \%$.

The tests conducted in an operational environment on the compositions selected with the dynamic eco-design validate the technological feasibility of the new materials, realizing a substantial product innovation (from composition $\mathrm{C} 1$ to $\mathrm{C} 6$ ) made possible by the re-engineering of the raw material supply system of the company, in compliance with R5 of the circular economy.

\section{Conclusions}

The circular economy represents a new organizational paradigm for manufacturing systems that drives companies to re-engineer activities and processes to make them sustainable, thanks to a conscious and efficient use of resources and production factors. The transition to the circular economy can be enabled by the development of digital technologies related to Industry 4.0, as they facilitate process and product innovation thanks to their high potential for tracking resource consumption and emissions. This study has provided empirical validation in an operational environment of the conceptual assumptions related to the enabling potential of digital technologies for the circular economy. Therefore, the results obtained from this experimentation provide implications of both a theoretical and managerial perspective and identify areas that require further investigation in future lines of research.

\subsection{Implications for Scholars}

This research has shown that the digital technologies of the Industry 4.0 environment really can help companies embark on a path toward circularity, not only based on the increased operational efficiency implicit in smart manufacturing but also by promoting a trajectory of organizational innovation. It is based on integrating two categories of production factors: tangible resources (materials and machinery) and intangible resources (data). Therefore, the enabling factor of circularity and, more generally, of sustainability becomes the ability of the manufacturing firm that is already efficient from an operational point of view to analyze the raw information intelligently collected by the equipment, i.e., to transform data from a simple accumulation of records (Big Data) into high-value assets (Smart Data). 
From the large availability of Big Data, helpful information was selected to conduct a predictive assessment of environmental impacts corresponding to different procurement scenarios. This allowed the selection of the best solution from an environmental and technological point of view and, therefore, the re-engineering of the ceramic product. This predictive approach, based on Life Cycle Assessment and microstructural analysis of materials, has been called circular eco-design precisely because it responds to the fifth of the 6 Rs of the circular economy: redesign.

Therefore, this empirical validation of the theoretical hypotheses that emerged from the literature fills the knowledge gaps highlighted in the introduction paragraph: the enabling potential of digital technologies for the circular economy and the transformation of Big Data into Smart Data to create value.

\subsection{Implications for Industry Practitioners}

The theoretical contribution of this study has direct consequences from the perspective of practitioners and organizations. Smart Data has made it possible to highlight new circular opportunities, exploiting the full potential of Industry 4.0 to achieve significant environmental benefits. Circular eco-design has highlighted how distances between the source of supply of raw materials and the factory and the type of transport are together key factors for the environmental sustainability of the finished product. Through a life cycle approach and the use of technological characterization techniques of materials, this research has shown how it can change the paradigm of product design. In the case of ceramic materials, the industrial practice has always seen technologists formulating body compositions whose sodium/potassium ratio was strongly unbalanced in favor of sodium. This conviction has led companies to oversaturate with extra-EU sodium feldspar to maintain a high level of sintering of the ceramic body to obtain low porosity. Ecodesign and empirical testing in laboratory and pilot environments have challenged this assumption, also demonstrating that with a strong reduction in imported sodium feldspar to the advantage of domestic potassium feldspar, it is possible to obtain a fully sintered and technologically performing ceramic body. With the same logic, the quantity of Ukrainian clay in the composition of the ceramic bodies was progressively reduced in favor of the German clay supplied to the factory by train and of a national clay. Both raw materials benefit from a transport system with low environmental impact.

From the point of view of industry practitioners, a virtuous circle of circular innovation has thus been created:

1. Digital technologies have enabled the smart exploitation of Big Data;

2. Smart Data has enabled circular eco-design that has led to product innovation;

3. Product innovation has favored the re-engineering of the raw material sourcing system;

4. The company moved a further step toward transitioning to the circular economy.

\subsection{Limitation and Future Research}

In addition to the theoretical and practitioner contributions, this research also has some limitations that represent suggestions for future research directions listed below.

1. Empirical validation of the theoretical hypotheses was carried out on a single case study. Although this methodological approach is widely used in the literature, and the company involved is one of the most representative in the ceramic sector, it would be appropriate to test the circular eco-design model with other companies, even in different sectors.

2. The Italian ceramic sector is certainly exemplary of a resource-intensive industry with a high level of process digitalization and environmental best practices. Therefore, the approach followed in this research should be tested in other manufacturing sectors that are less evolved from an Industry 4.0 and environmental viewpoint.

3. The circular eco-design model adopted in this study considered only the environmental dimension of sustainability without including the economic and social dimensions. 
Therefore, the question of the multidimensionality of the circular economy to go beyond only environmental aspects remains open.

4. The results show a strong link between environmental and technological performance. This relationship, along with that between technological performance and social and economic ones, are to be further investigated.

5. The interdependence between $\mathrm{Na}_{2} \mathrm{O} / \mathrm{K}_{2} \mathrm{O}$ and $\mathrm{SiO}_{2} / \mathrm{Al}_{2} \mathrm{O}_{3}$ ratios and the degree of sintering of a ceramic body that arose from the results of this study require further investigation, as well as the effect of the chemical nature and quantity of the glass phase formed during firing on the degree of sintering of the ceramic body.

Author Contributions: Conceptualization, M.V. and D.S.-B.; investigation, M.V.; formal analysis, M.V.; data curation, E.I.C.-G.; methodology, A.M.F.; validation, C.S.; supervision, C.S.; writing-original draft preparation, D.S.-B.; writing-review and editing, D.S.-B. All authors have read and agreed to the published version of the manuscript.

Funding: This research was co-funded by the European Union under the LIFE Program, grant number: LIFE16ENV/IT/000307 (LIFE Force of the Future).

Institutional Review Board Statement: Not applicable.

Informed Consent Statement: Not applicable.

Data Availability Statement: Data presented in this study are available upon request to the corresponding author.

Conflicts of Interest: The authors declare no conflict of interest.

\section{References}

1. Khanzode, A.G.; Sarma, P.R.S.; Mangla, S.K.; Yuan, H. Modeling the Industry 4.0 adoption for sustainable production in Micro, Small \& Medium Enterprises. J. Clean. Prod. 2021, 279, 123489. [CrossRef]

2. Thomson, L.; Kamalaldin, A.; Sjödin, D.; Parida, V. A maturity framework for autonomous solutions in manufacturing firms: The interplay of technology, ecosystem, and business model. Int. Entrep. Manag. J. 2021, 1-28. [CrossRef]

3. Zambetti, M.; Adrodegari, F.; Pezzotta, G.; Pinto, R.; Rapaccini, M.; Barbieri, C. From data to value: Conceptualising data-driven product service system. Prod. Plan. Control 2021, 1-17. [CrossRef]

4. Horick, C. Industry 4.0 production networks: Cyber-physical system-based smart factories, real-time big data analytics, and sustainable product lifecycle management. J. Self-Gov. Manag. Econ. 2020, 8, 107-113. [CrossRef]

5. Ghouri, A.M.; Mani, V.; Jiao, Z.; Venkatesh, V.G.; Shi, Y.; Kamble, S.S. An empirical study of real-time information-receiving using industry 4.0 technologies in downstream operations. Technol. Forecast. Soc. Chang. 2021, 165, 120551. [CrossRef]

6. Romero, C.A.T.; Castro, D.F.; Ortiz, J.H.; Khalaf, O.I.; Vargas, M.A. Synergy between circular economy and industry 4.0: A literature review. Sustainability 2021, 13, 4331. [CrossRef]

7. Sharma, N.K.; Govindan, K.; Lai, K.K.; Chen, W.K.; Kumar, V. The transition from linear economy to circular economy for sustainability among SMEs: A study on prospects, impediments, and prerequisites. Bus. Strateg. Environ. 2021, 30, 1803-1822 [CrossRef]

8. D'Adamo, I.; Ferella, F.; Gastaldi, M.; Maggiore, F.; Rosa, P.; Terzi, S. Towards sustainable recycling processes: Wasted printed circuit boards as a source of economic opportunities. Resour. Conserv. Recycl. 2019, 149, 455-467. [CrossRef]

9. Santana, A.; Afonso, P.; Zanin, A.; Wernke, R. Costing models for capacity optimization in Industry 4.0: Trade-off between used capacity and operational efficiency. Procedia Manuf. 2017, 13, 1183-1190. [CrossRef]

10. D'Adamo, I.; Rosa, P. How do you see infrastructure? Green energy to provide economic growth after COVID-19. Sustainability 2020, 12, 4738. [CrossRef]

11. Ferrari, A.M.; Volpi, L.; Pini, M.; Siligardi, C.; García-Muiña, F.E.; Settembre-Blundo, D. Building a sustainability benchmarking framework of ceramic tiles based on life cycle sustainability assessment (LCSA). Resources 2019, 8, 11. [CrossRef]

12. Marzouk, M.; Azab, S. Environmental and economic impact assessment of construction and demolition waste disposal using system dynamics. Resour. Conserv. Recycl. 2014, 82, 41-49. [CrossRef]

13. Khorassani, S.M.; Ferrari, A.M.; Pini, M.; Blundo, D.S.; Muiña, F.E.G.; García, J.F. Environmental and social impact assessment of cultural heritage restoration and its application to the Uncastillo Fortress. Int. J. Life Cycle Assess. 2019, 24, 1297-1318. [CrossRef]

14. Vacchi, M.; Siligardi, C.; Demaria, F.; Cedillo-González, E.I.; González-Sánchez, R.; Settembre-Blundo, D. Technological Sustainability or Sustainable Technology? A Multidimensional Vision of Sustainability in Manufacturing. Sustainability 2021, $13,9942$. [CrossRef]

15. Mahbub, N.; Oyedun, A.O.; Zhang, H.; Kumar, A.; Poganietz, W.R. A life cycle sustainability assessment (LCSA) of oxymethylene ether as a diesel additive produced from forest biomass. Int. J. Life Cycle Assess. 2019, 24, 881-899. [CrossRef] 
16. Azarmipour, M.; Elfaham, H.; Gries, C.; Kleinert, T.; Epple, U. A Service-based Architecture for the Interaction of Control and MES Systems in Industry 4.0 Environment. In Proceedings of the 2020 IEEE 18th International Conference on Industrial Informatics (INDIN), Warwick, UK, 20-23 July 2020; pp. 217-222.

17. Bressanelli, G.; Perona, M.; Saccani, N. Challenges in supply chain redesign for the Circular Economy: A literature review and a multiple case study. Int. J. Prod. Res. 2019, 57, 7395-7422. [CrossRef]

18. Resman, M.; Turk, M.; Herakovic, N. Methodology for planning smart factory. Procedia CIRP 2020, 97, 401-406. [CrossRef]

19. Agrawal, R.; Wankhede, V.A.; Kumar, A.; Upadhyay, A.; Garza-Reyes, J.A. Nexus of circular economy and sustainable business performance in the era of digitalization. Int. J. Product. Perform. Manag. 2021. ahead-of-print. [CrossRef]

20. Spaltini, M.; Poletti, A.; Acerbi, F.; Taisch, M. A quantitative framework for Industry 4.0 enabled Circular Economy. Procedia CIRP 2021, 98, 115-120. [CrossRef]

21. Pieroni, M.P.P.; McAloone, T.C.; Pigosso, D.C.A. Developing a process model for circular economy business model innovation within manufacturing companies. J. Clean. Prod. 2021, 299, 126785. [CrossRef]

22. D'Adamo, I.; Gastaldi, M.; Rosa, P. Recycling of end-of-life vehicles: Assessing trends and performances in Europe. Technol. Forecast. Soc. Chang. 2020, 152, 119887. [CrossRef]

23. Bressanelli, G.; Saccani, N.; Perona, M.; Baccanelli, I. Towards circular economy in the household appliance industry: An overview of cases. Resources 2020, 9, 128. [CrossRef]

24. Han, J.; Heshmati, A.; Rashidghalam, M. Circular economy business models with a focus on servitization. Sustainability 2020, 12, 8799. [CrossRef]

25. Hapuwatte, B.M.; Jawahir, I.S. Closed-loop sustainable product design for circular economy. J. Ind. Ecol. 2021. [CrossRef]

26. Waibel, M.W.; Steenkamp, L.P.; Moloko, N.; Oosthuizen, G.A. Investigating the Effects of Smart Production Systems on Sustainability Elements. Procedia Manuf. 2017, 8, 731-737. [CrossRef]

27. García-Quevedo, J.; Jové-Llopis, E.; Martínez-Ros, E. Barriers to the circular economy in European small and medium-sized firms. Bus. Strateg. Environ. 2020, 29, 2450-2464. [CrossRef]

28. Jørgensen, M.S.; Remmen, A. A Methodological Approach to Development of Circular Economy Options in Businesses. Procedia CIRP 2018, 69, 816-821. [CrossRef]

29. Pazoki, M.; Samarghandi, H. Take-back regulation: Remanufacturing or Eco-design? Int. J. Prod. Econ. 2020, 227, 107674. [CrossRef]

30. Rajput, S.; Singh, S.P. Industry 4.0-Challenges to implement circular economy. Benchmarking 2019, 28, 1717-1739. [CrossRef]

31. Maccioni, L.; Borgianni, Y.; Pigosso, D.C.A. Can the choice of eco-design principles affect products' success? Des. Sci. 2019, 5, e25. [CrossRef]

32. Barbosa, A.J.D.; de Paiva Santos, V.H.; de Araújo, P.C.; de Medeiros, F.L.; da Silva Otaviano, L.Y. Eco product development combining eco design and life cycle assessment. Benchmarking 2021, 28, 502-516. [CrossRef]

33. da Luz, L.M.; de Francisco, A.C.; Piekarski, C.M.; Salvador, R. Integrating life cycle assessment in the product development process: A methodological approach. J. Clean. Prod. 2018, 193, 28-42. [CrossRef]

34. Dev, N.K.; Shankar, R.; Swami, S. Diffusion of green products in industry 4.0: Reverse logistics issues during design of inventory and production planning system. Int. J. Prod. Econ. 2020, 223, 107519. [CrossRef]

35. Patrucco, A.; Ciccullo, F.; Pero, M. Industry 4.0 and supply chain process re-engineering: A coproduction study of materials management in construction. Bus. Process Manag. J. 2020, 26, 1093-1119. [CrossRef]

36. Tripathi, S.; Gupta, M. A framework for procurement process re-engineering in Industry 4.0. Bus. Process Manag. J. 2021, 27, 439-458. [CrossRef]

37. Brad, E.; Brad, S. Algorithm for designing reconfigurable equipment to enable industry 4.0 and circular economy-driven manufacturing systems. Appl. Sci. 2021, 11, 4446. [CrossRef]

38. Zheng, T.; Ardolino, M.; Bacchetti, A.; Perona, M. The applications of Industry 4.0 technologies in manufacturing context: A systematic literature review. Int. J. Prod. Res. 2021, 59, 1922-1954. [CrossRef]

39. Lacam, J.-S.; Salvetat, D. Big data and Smart data: Two interdependent and synergistic digital policies within a virtuous data exploitation loop. J. High Technol. Manag. Res. 2021, 32, 100406. [CrossRef]

40. Kumar, P.; Singh, R.K.; Kumar, V. Managing supply chains for sustainable operations in the era of industry 4.0 and circular economy: Analysis of barriers. Resour. Conserv. Recycl. 2021, 164, 105215. [CrossRef]

41. Beltrami, M.; Orzes, G.; Sarkis, J.; Sartor, M. Industry 4.0 and sustainability: Towards conceptualization and theory. J. Clean. Prod. 2021, 312, 127733. [CrossRef]

42. Badhotiya, G.K.; Avikal, S.; Soni, G.; Sengar, N. Analyzing barriers for the adoption of circular economy in the manufacturing sector. Int. J. Product. Perform. Manag. 2021, ahead-of-print. [CrossRef]

43. Blundo, D.S.; García-Muiña, F.E.; Pini, M.; Volpi, L.; Siligardi, C.; Ferrari, A.M. Sustainability as source of competitive advantages in mature sectors: The case of Ceramic District of Sassuolo (Italy). Smart Sustain. Built Environ. 2019, 8, 53-79. [CrossRef]

44. Dondi, M.; García-Ten, J.; Rambaldi, E.; Zanelli, C.; Vicent-Cabedo, M. Resource efficiency versus market trends in the ceramic tile industry: Effect on the supply chain in Italy and Spain. Resour. Conserv. Recycl. 2021, 168, 105271. [CrossRef]

45. Garcia-Muiña, F.E.; González-Sánchez, R.; Ferrari, A.M.; Volpi, L.; Pini, M.; Siligardi, C.; Settembre-Blundo, D. Identifying the equilibrium point between sustainability goals and circular economy practices in an Industry 4.0 manufacturing context using eco-design. Soc. Sci. 2019, 8, 241. [CrossRef] 
46. García-Muiña, F.E.; Medina-Salgado, M.S.; Ferrari, A.M.; Cucchi, M. Sustainability Transition in Industry 4.0 and Smart Manufacturing with the Triple-Layered Business Model Canvas. Sustainability 2020, 12, 2364. [CrossRef]

47. Boschi, G.; Masi, G.; Bonvicini, G.; Bignozzi, M.C. Sustainability in Italian ceramic tile production: Evaluation of the environmental impact. Appl. Sci. 2020, 10, 9063. [CrossRef]

48. Confindustria Ceramica. Environmental Product Declaration: Italian Ceramic Tiles; EPD-COI-20160202-ICG1-EN; Institut Bauen und Umwelt e.V. (IBU): Berlin, Germany, 2016.

49. Confindustria Ceramica. National Statistical Survey on Italian Ceramic Tile Industry; Confindustria Ceramica: Sassuolo, Italy, 2020; Volume 41.

50. Esteller-Cucala, M.; Fernandez, V.; Villuendas, D. Towards data-driven culture in a Spanish automobile manufacturer: A case study. J. Ind. Eng. Manag. 2020, 13, 228-245. [CrossRef]

51. Mishra, O. Principles of frugal innovation and its application by social entrepreneurs in times of adversity: An inductive single-case approach. J. Entrep. Emerg. Econ. 2021. ahead-of-print. [CrossRef]

52. Margherita, E.G.; Braccini, A.M. Examining the development of a digital ecosystem in an Industry 4.0 context: A sociotechnical perspective. SN Bus. Econ. 2021, 1, 89. [CrossRef]

53. Candelo, E.; Troise, C.; Matricano, D.; Lepore, A.; Sorrentino, M. The evolution of the pathways of innovation strategies in the automotive industry. The case of Fiat Chrysler Automobiles. Eur. J. Innov. Manag. 2021. ahead-of-print. [CrossRef]

54. Murmura, F.; Bravi, L.; Santos, G. Sustainable Process and Product Innovation in the Eyewear Sector: The Role of Industry 4.0 Enabling Technologies. Sustainability 2021, 13, 365. [CrossRef]

55. Strandhagen, J.W.; Buer, S.-V.; Semini, M.; Alfnes, E.; Strandhagen, J.O. Sustainability challenges and how Industry 4.0 technologies can address them: A case study of a shipbuilding supply chain. Prod. Plan. Control 2020, 1-16. [CrossRef]

56. Machado, C.G.; Winroth, M.; Carlsson, D.; Almström, P.; Centerholt, V.; Hallin, M. Industry 4.0 readiness in manufacturing companies: Challenges and enablers towards increased digitalization. Procedia CIRP 2019, 81, 1113-1118. [CrossRef]

57. Braccini, A.M.; Margherita, E.G. Exploring organizational sustainability of Industry 4.0 under the triple bottom line: The case of a manufacturing company. Sustainability 2018, 11, 36. [CrossRef]

58. Brasileiro, C.T.; Conte, S.; Contartesi, F.; Melchiades, F.G.; Zanelli, C.; Dondi, M.; Boschi, A.O. Effect of strong mineral fluxes on sintering of porcelain stoneware tiles. J. Eur. Ceram. Soc. 2021, 41, 5755-5767. [CrossRef]

59. Medina-Salgado, M.S.; García-Muiña, F.E.; Cucchi, M.; Settembre-Blundo, D. Adaptive life cycle costing (Lcc) modeling and applying to italy ceramic tile manufacturing sector: Its implication of open innovation. J. Open Innov. Technol. Mark. Complex. 2021, 7, 101. [CrossRef]

60. Settembre-Blundo, D.; González-Sánchez, R.; Medina-Salgado, S.; García-Muiña, F.E. Flexibility and Resilience in Corporate Decision Making: A New Sustainability-Based Risk Management System in Uncertain Times. Glob. J. Flex. Syst. Manag. 2021, 1-26. [CrossRef]

61. European Council Directive 2009/125/EC of the European Parliament and of the Council of 21 October 2009 establishing a framework for the setting of ecodesign requirements for energy-related products (recast). Off. J. Eur. Union 2009, 52, 10-35.

62. Navajas, A.; Uriarte, L.; Gandía, L.M. Application of eco-design and life cycle assessment standards for environmental impact reduction of an industrial product. Sustainability 2017, 9, 1724. [CrossRef]

63. Toniolo, S.; Tosato, R.C.; Gambaro, F.; Ren, J. Life cycle thinking tools: Life cycle assessment, life cycle costing and social life cycle assessment. In Life Cycle Sustainability Assessment for Decision-Making: Methodologies and Case Studies; Elsevier: Amsterdam, The Netherlands, 2019; pp. 39-56.

64. Dondi, M.; Guarini, G.; Raimondo, M.; Falucci, S. Influence of mineralogy and particle size on the technological properties of ball clays for porcelain stoneware tiles. Tile Brick Int. 2003, 20, 2-11.

65. Dondi, M.; Raimondo, M.; Zanelli, C. Clays and bodies for ceramic tiles: Reappraisal and technological classification. Appl. Clay Sci. 2014, 96, 91-109. [CrossRef]

66. Ohbuchi, A.; Koike, Y.; Nakamura, T. Quantitative phase analysis of fly ash of municipal solid waste by X-ray powder diffractometry/Rietveld refinement. J. Mater. Cycles Waste Manag. 2019, 21, 829-837. [CrossRef]

67. Larson, A.C.; Von Dreele, R.B. Generalized Structure Analysis System (GSAS) LAUR 86-748; Los Alamos National Laboratory: Los Alamos, NM, USA, 1994.

68. Toby, B.H. EXPGUI, a graphical user interface for GSAS. J. Appl. Crystallogr. 2001, 34, 210-213. [CrossRef]

69. Conte, S.; Zanelli, C.; Ardit, M.; Cruciani, G.; Dondi, M. Phase evolution during reactive sintering by viscous flow: Disclosing the inner workings in porcelain stoneware firing. J. Eur. Ceram. Soc. 2020, 40, 1738-1752. [CrossRef]

70. Correia, S.L.; Dienstmann, G.; Folgueras, M.V.; Segadaes, A.M. Effect of quartz sand replacement by agate rejects in triaxial porcelain. J. Hazard. Mater. 2009, 163, 315-322. [CrossRef]

71. Wernet, G.; Bauer, C.; Steubing, B.; Reinhard, J.; Moreno-Ruiz, E.; Weidema, B. The ecoinvent database version 3 (part I): Overview and methodology. Int. J. Life Cycle Assess. 2016, 21, 1218-1230. [CrossRef]

72. Ferrari, A.M.; Volpi, L.; Settembre-Blundo, D.; García-Muiña, F.E. Dynamic life cycle assessment (LCA) integrating life cycle inventory (LCI) and Enterprise resource planning (ERP) in an industry 4.0 environment. J. Clean. Prod. 2021, 286, 125314. [CrossRef]

73. Pauer, E.; Wohner, B.; Tacker, M. The influence of database selection on environmental impact results. Life cycle assessment of packaging using gabi, ecoinvent 3.6, and the environmental footprint database. Sustainability 2020, 12, 9948. [CrossRef] 
74. PRé Sustainability SimaPro I The World's Leading LCA Software. 2020. Available online: https://simapro.com/ (accessed on 14 September 2021).

75. Abyar, H.; Younesi, H.; Nowrouzi, M. Life cycle assessment of A2O bioreactor for meat processing wastewater treatment: An endeavor toward the achievement of environmental sustainable development. J. Clean. Prod. 2020, 257, 120575. [CrossRef]

76. Pini, M.; Breglia, G.; Venturelli, M.; Montorsi, L.; Milani, M.; Neri, P.; Ferrari, A.M. Life cycle assessment of an innovative cogeneration system based on the aluminum combustion with water. Renew. Energy 2020, 154, 532-541. [CrossRef]

77. EN 15804:2012+A2:2019. Available online: http:/ / store.uni.com/catalogo/en-15804-2012-a2-2019 (accessed on 12 August 2021).

78. Zanelli, C.; Raimondo, M.; Guarini, G.; Dondi, M. The vitreous phase of porcelain stoneware: Composition, evolution during sintering and physical properties. J. Non-Cryst. Solids 2011, 357, 3251-3260. [CrossRef]

79. Mugoni, C.; Rosa, R.; Remigio, V.A.; Ferrari, A.M.; Siligardi, C. Opportune inward waste materials toward a zero waste ceramic slabs production in a circular economy perspective. Int. J. Appl. Ceram. Technol. 2020, 17, 32-41. [CrossRef]

80. Al-Shantir, O.; Csáki, Š.; Veverka, J.; Trník, A. The influence of compression pressure on thermal expansion, bulk density, and Young's modulus of electroporcelain mixture up to $1100^{\circ} \mathrm{C}$. J. Therm. Anal. Calorim. 2019, 138, 2035-2042. [CrossRef]

81. Rodriguez-Navarro, C.; Cultrone, G.; Sanchez-Navas, A.; Sebastian, E. TEM study of mullite growth after muscotive breakdown. Am. Mineral. 2003, 88, 713-724. [CrossRef]

82. Chauhan, A. Powder XRD Technique and its Applications in Science and Technology. J. Anal. Bioanal. Tech. 2014, 5, 5. [CrossRef]

83. Ban, T.; Okada, K. Structure Refinement of Mullite by the Rietveld Method and a New Method for Estimation of Chemical Composition. J. Am. Ceram. Soc. 1992, 75, 227-230. [CrossRef]

84. Giordano, D.; Russell, J.K.; Dingwell, D.B. Viscosity of magmatic liquids: A model. Earth Planet. Sci. Lett. 2008, 271, 123-134. [CrossRef]

85. Conte, S.; Zanelli, C.; Ardit, M.; Cruciani, G.; Dondi, M. Predicting viscosity and surface tension at high temperature of porcelain stoneware bodies: A methodological approach. Materials 2018, 11, 2475. [CrossRef] [PubMed]

86. Vieira, A.W.; De Mello Innocentini, M.D.; Mendes, E.; Gomes, T.; Demarch, A.; Montedo, O.R.K.; Angioletto, E. Comparison of methods for determining the water absorption of glazed porcelain stoneware ceramic tiles. Mater. Res. 2017, 20, 637-643. [CrossRef]

87. Barrachina, E.; Esquinas, M.; Llop, J.; Notari, M.D.; Carda, J.B. Development of a glass-ceramic glaze formulated from industrial residues to improve the mechanical properties of the porcelain stoneware tiles. Mater. Lett. 2018, 220, 226-228. [CrossRef]

88. Luo, Y.; Ma, S.; Zheng, S.; Liu, C.; Han, D.; Wang, X. Mullite-based ceramic tiles produced solely from high-alumina fly ash: Preparation and sintering mechanism. J. Alloys Compd. 2018, 732, 828-837. [CrossRef] 